OECDpublishing

\title{
THE LAKE TAUPO \\ NITROGEN MARKET \\ IN NEW ZEALAND
}

A REVIEW FOR POLICY MAKERS

OECD ENVIRONMENT POLICY PAPER

September 2015 n04 


\section{The Lake Taupo Nitrogen Market in New Zealand}

Lessons in environmental policy reform

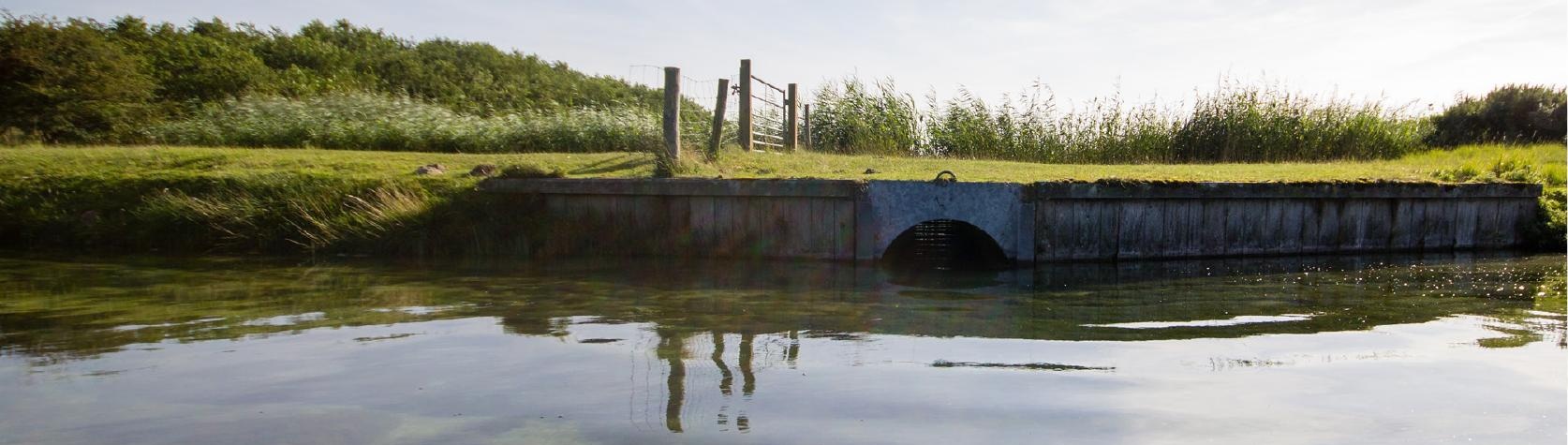

OECD ENVIRONMENT POLICY PAPER NO. 4

SEPTEMBER 2015

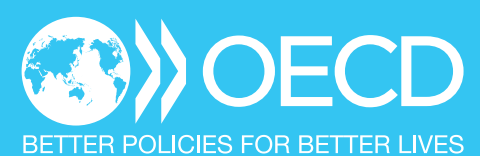




\section{Disclaimers}

The OECD Environment Policy Papers are published under the responsibility of the Secretary-General of the OECD. The opinions expressed and the arguments employed herein do not necessarily reflect the official views of OECD member countries.

This document and any map included herein are without prejudice to the status of or sovereignty over any territory, to the delimitation of international frontiers and boundaries and to the name of any territory, city or area.

The statistical data for Israel are supplied by and under the responsibility of the relevant Israeli authorities. The use of such data by the OECD is without prejudice to the status of the Golan Heights, East Jerusalem and Israeli settlements in the West Bank under the terms of international law.

\section{Copyright}

You can copy, download or print OECD content for your own use, and you can include excerpts from OECD publications, databases and multimedia products in your own documents, presentations, blogs, websites and teaching materials, provided that suitable acknowledgment of OECD as source and copyright owner is given. All requests for public or commercial use and translation rights should be submitted to rights@ oecd.org. Requests for permission to photocopy portions of this material for public or commercial use shall be addressed directly to the Copyright Clearance Center (CCC) at info@copyright.com or the Centre français d'exploitation du droit de copie (CFC) at contact@cfcopies.com.

\section{ISSN 2309-7841}

Authorised for publication by Simon Upton

Director, Environment Directorate 


\section{The Lake Taupo Nitrogen Market in New Zealand}

Lessons in environmental policy reform

OECD ENVIRONMENT POLICY PAPER NO. 4

SEPTEMBER 2015

\section{Contents}

1. The environmental problem 2

2. The policy challenge: reducing nitrogen discharge $\quad 4$ levels

3. The policy response: the nutrient cap and trade 5 project

4. Policy implementation and progress $\quad 10$

5. Environmental and economic impacts 12

6. Social impacts 14

7. Lessons learned 15

8. References 17 


\section{The Lake Taupo Nitrogen Market in New Zealand}

Lessons in environmental policy reform

\section{Key messages}

\section{The problem}

Nitrogen run-off from farming and other land uses was threatening to undermine the pristine waters of Lake Taupo - New Zealand's largest and most iconic lake - and to damage a range of economic and cultural activities.

\section{The policy response}

In 2011, the regional government introduced a water quality policy package with three components: (1) a cap on nitrogen emission levels within the Lake Taupo catchment; (2) the establishment of the Taupo nitrogen market; and (3) the formation of the Lake Taupo Protection Trust to fund the initiative. This bold policy experiment is globally unique: it is the only trading programme or market where diffuse sources of pollution operate under a cap.

\section{The impact}

By 2015 , the target of reducing nitrogen discharges by 170 tonnes $-20 \%$ of manageable nitrogen emissions - had been met, three years ahead of time and on budget. Whether this is adequate to maintain water quality in the lake is more difficult to assess, given the long timescales involved in groundwater filtration. Trading activity and transaction cost estimates suggest the market is functioning well.

This experience shows that it is technically feasible to include non-point sources within a capand-trade water quality market, that such a market can function, and that once property rights are clearly established, the additional cost of allowing trading is low. The journey to policy implementation was lengthy, requiring leadership and commitment from politicians, landowners and staff at all levels of government, but ultimately positive. Compromises were essential to successful implementation. 


\section{The environmental problem}

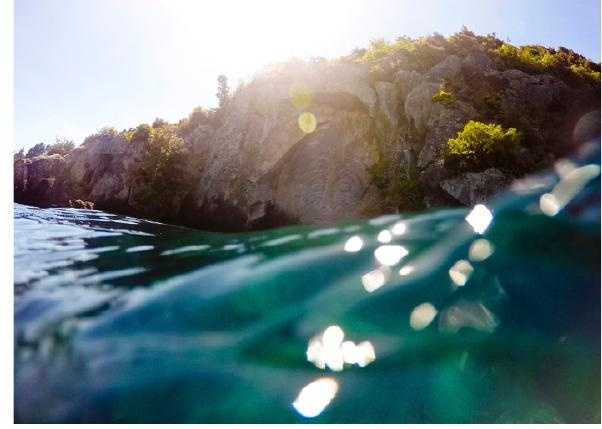

Lake Taupo is New Zealand's largest lake, and a national icon. Its pristine waters attract visitors from round the world for a multitude of water-based recreation and sight-seeing activities. It is also important to New Zealand's indigenous peoples. ${ }^{1}$

In the late 1990s, scientific investigations by Environment Waikato (now the Waikato Regional Council), the regional authority responsible for environmental management in the Lake Taupo catchment, revealed that water quality in Lake Taupo was gradually declining. The research identified that nitrogen emissions were entering the lake from both natural processes and human activities, such as pastoral farming, urban runoff and wastewater (see Table 1). The total amount of nitrogen entering thelake was estimated at 1360 tonnes annually. Of the 556 tonnes of manageable (i.e. human-induced) emissions, 510 tonnes were from pastoral farming.

Lake Taupo is contained within a collapsed caldera formed from one of the world's largest eruptions, which took place 26000 years ago. The now dormant volcano has left a legacy of ejected pumice and ash over much of New Zealand's North Island and in particular in the catchment of the lake. This underlying layer of pumice makes the soil structure in the lake's catchment extremely permeable and allows the unrestricted movement of both water and contaminants into the water tables draining into the lake. Reducing contaminant inflows into the lake therefore needs to address the challenging issue of diffuse groundwater movements, which are largely unseen, and difficult to measure and predict. In some parts of the catchment, it can take more than 100 years for run-off nitrogen to reach the lake (Vant, 2008).

\section{Box 1 | The effects of nitrogen on water quality}

Scientists have seen an increase in chlorophyll a (an indicator of the amount of tiny, free-floating algae) in the lake's surface waters. There have also been increases in the amount of dissolved nitrogen in the bottom waters of the lake just prior to winter when the lake's bottom waters mix with its surface. Nitrogen is a staple food for plant life, promoting healthy, vigorous growth. The increasing amounts of nitrogen in the lake are feeding the growth of tiny free-floating algae in the water. More algae in the water reduces the water's clarity. Scientists are also seeing more nutrient-dependent weeds and slimes growing in sheltered waters near lakeshore settlements.

In 2001, for the first time, potentially toxic algae bloomed unexpectedly in the lake, resulting in health warnings being issued and pointing to deterioration of the Lake's health.

Source: www.waikatoregion.govt.nz/PageFiles/7058/strategy.PDF. 
The water quality deterioration identified in the late 1990s threatened the lake's future. While the lake water quality was still recognised as almost pristine, with very low levels of nitrogen, predictions were for the quality to decline over time and the risks of algal blooms to increase.

Thus began an 11-year policy process to manage human-induced nitrogen emissions to the lake that culminated in the introduction of a cap-and-trade programme to limit nitrogen entering the lake. Introducing regulation for diffuse nitrogen discharges challenged the long-held presumed rights of New Zealand landowners, and risked being overturned by agricultural political forces. Despite these obstacles, the process gave rise to individual and governmental leadership that has carried the project to completion. Innovative practices have emerged, including the use of nitrogen modelling software, the creation of a nitrogen trading market, and the development of a non-government agency to purchase nitrogen reductions by a public fund. This policy case study describes the approach taken, the challenges encountered and the environmental, economic and social impacts. It concludes by discussing the wider lessons that are raised for other governments seeking to develop similar policy responses.

\section{Table 1 | Sources of nitrogen losses in the Lake Taupo surface water}

\begin{tabular}{|c|c|c|c|c|c|c|}
\hline & \multicolumn{2}{|l|}{ Source } & $\begin{array}{l}\text { Load of } \mathrm{N} \\
\text { (tonnes/year) }\end{array}$ & $\begin{array}{l}\text { Effective Yield } \\
\text { (kgN/ha/year) }\end{array}$ & $\begin{array}{l}\% \\
\text { Total }\end{array}$ & $\begin{array}{l}\text { \% Sources } \\
\text { Category }\end{array}$ \\
\hline \multirow{6}{*}{ 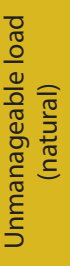 } & \multicolumn{2}{|c|}{ Atmospheric deposition } & 272 & 4.4 & $20 \%$ & $34 \%$ \\
\hline & \multicolumn{2}{|c|}{ Undeveloped land } & 311 & 2 & $23 \%$ & $39 \%$ \\
\hline & \multicolumn{2}{|c|}{ Pine on unimproved land } & 122 & 2 & $9 \%$ & $15 \%$ \\
\hline & \multicolumn{2}{|c|}{ Tongariro Power Development } & 87 & & $6 \%$ & $11 \%$ \\
\hline & \multicolumn{2}{|c|}{ Pine on unimproved pasture } & 12 & 2.7 & $1 \%$ & $1 \%$ \\
\hline & \multicolumn{2}{|r|}{ Subtotal } & 804 & \multicolumn{3}{|c|}{$59 \%$} \\
\hline \multirow{7}{*}{ 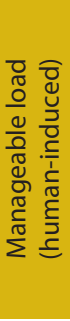 } & \multirow{2}{*}{ Pastoral } & Non-dairy pasture & 442 & 8.6 & $33 \%$ & $79 \%$ \\
\hline & & Dairy pasture & 68 & 29 & $5 \%$ & $12 \%$ \\
\hline & \multicolumn{2}{|c|}{ Urban runoff } & 16 & 8 & $1 \%$ & $3 \%$ \\
\hline & \multicolumn{2}{|c|}{ Wastewater } & 17 & & $1 \%$ & $3 \%$ \\
\hline & \multicolumn{2}{|c|}{ Pine on improved pasture } & 6 & $4.2-6.0^{b}$ & $0.4 \%$ & $1 \%$ \\
\hline & \multicolumn{2}{|c|}{ Nitrogen-fixing scrub } & 7 & 12 & $0.5 \%$ & $1 \%$ \\
\hline & & Subtotal & 556 & & $41 \%$ & \\
\hline & & Total & 1360 & & $100 \%$ & \\
\hline
\end{tabular}

Notes: (a) This estimate of the breakdown of nitrogen sources and total agreed nitrogen load is a best estimate from 2008.

(b) Note that pine on improved pasture is assumed to trend down to $3 \mathrm{~kg} / \mathrm{ha} / \mathrm{year}$ long-term average. Source: Environmental Court, 2008. 
For farmers, intensifying farming effort and changing land use was a presumed right that added considerable capital value to their land asset. The capital value of the land is important to farmers; it provides a long-run tax-free ${ }^{2}$ return in a country where typically farm income is low and inter-generational farming is not the norm. For many farmers, the proceeds from the sale of the farm asset represent their retirement savings.

The Taupo policy package described here was seen to directly challenge, for the first time in New Zealand, the presumed right of farmers to operate farming activities without restrictions. In essence, this therefore not only challenged their ability to expand their operations, but was also likely to affect their eventual capital gain from any sale of their land. This became the backdrop to the policy challenge and created the impetus to seek both positive environmental and economic outcomes.

\section{The policy response: the nutrient cap and trade project}

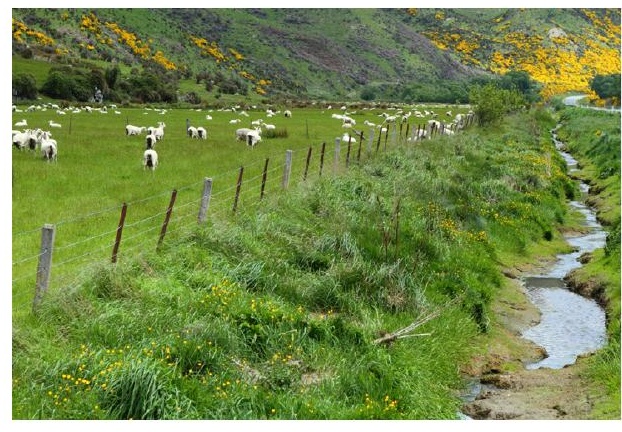

Soon after the water quality problem was identified by the Waikato Regional Council in the late 1990s, discussions with the community began. The initial contact by the Regional Council was via a pamphlet to the Taupo community describing the water quality issue, the causes, and identifying limits on fertiliser use and changes from intensive agriculture as potential measures to preserve water quality in the lake. In 2000, the Regional Council set up meetings with landowners to discuss the issue further. Farmers recall being told they were responsible for polluting the lake and were outraged, given that the New Zealand farming model encouraged and rewarded high productivity (Yerex, 2009). Taupo farmers also felt they had already countered their environmental impacts with extensive stream fencing, planting and retirement under a Taupo Catchment Control Scheme in the 1970s. The notion that they were polluters was a novel and unwelcome concept.

This led the Regional Council to review its approach to the community. Not addressing the water quality issue was not an option; a process that would constructively engage the community was needed. So began regular and frequent meetings between Regional Council staff and landowners, working to understand each other's needs and develop a policy to save the lake and allow communities to survive and prosper. These meetings 
would continue up to the time of Environment Court hearings associated with the policy changes in 2007. A Memorandum of Understanding between the Waikato Regional Council and Taupo Lake Care established ground rules for consultation and helped build trust with landowners. It took approximately 11 years from early consultation with the community to the final decision of the courts, including six years of formal legislative process. While this extensive period of time allowed all the issues to be fully examined, it required significant commitment from all involved.

The outcome was a target to reduce manageable nitrogen emissions to $20 \%$ below current recorded levels, so as to restore water quality and clarity to 2001 levels by 2080 . This was equivalent to 153 tonnes of nitrogen annual discharge reduction by 2018. However, this target was a compromise: there was strong debate and uncertainty over the size of the reduction, with estimates ranging between $20 \%$ and $80 \%$. The legislation required that the environmental benefits of a higher nitrogen reduction target be considered against the economic, social and cultural effects of the decision. A higher nitrogen reduction target was likely to have major impacts on the viability of farming, and consequent negative impacts on the wider community. Thus, the more modest figure of $20 \%$ was considered a scientifically defensible target, given the scientific uncertainty and the broader interests at stake (Waikato Regional Council, 2011).

This was to be achieved through a policy package with three main components designed to give landowners flexibility, while managing overall nitrogen emissions (Figure 1):

(1) A cap on nitrogen emission levels within the Lake Taupo catchment.

(2) The establishment of the Taupo nitrogen market.

(3) The formation of the Lake Taupo Protection Trust to fund the initiative.

Known as "Variation 5", the policy package simultaneously aimed to minimise the costs and mitigate the social and cultural effects of achieving the cut in nitrogen emissions. The costs were to be spread across local, regional, and national communities. The creation of a market for managing diffuse emissions was the first of its kind in New Zealand, and rare around the world. 


\section{Figure 1 | A three-point strategy to improve water quality}

\section{Catchment cap}

Regulate non-point agricultural sources to constrain agricultural nitrogen (N) load to Lake Taupo at "current" tonnes N (915 tonnes)
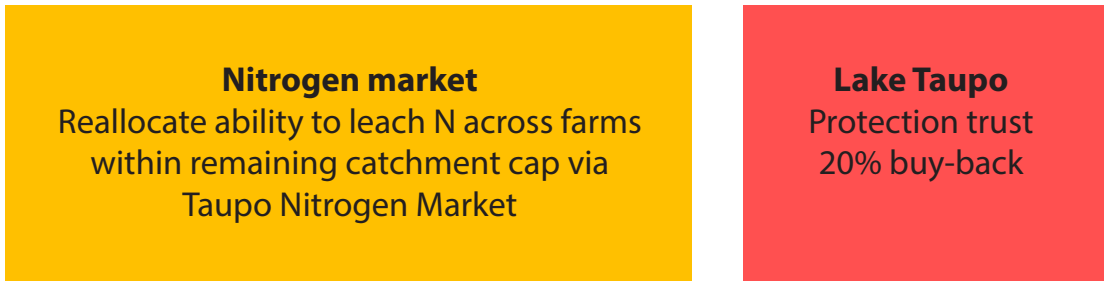

Notes: (a) Lake Taupo Protection Trust (2011). OVERSEER ${ }^{\bullet}$ model produced figure.

Source: Kerr at al. (2015)

\section{Capping nitrogen levels}

The cap on nitrogen was regulated through land use and discharge controls. Each farm was allocated an individually-calculated nitrogen discharge allowance, consistent with the desired reduction in emission levels. This permitted them to leach a certain level of nitrogen every year, based on their previous levels of nitrogen use. This approach, known as "grandparenting", was controversial (see Box 2). 


\section{Box 2 | Understanding grandparenting}

The allocation of nitrogen discharge allowances became one of the most contentious issues during the policy formation phase, as it was foreseen that nitrogen discharge allowances, in addition to allowing existing operations to function, would eventually have value in any trading system. The policy allocated the allowances using an existing use approach, also known as "grandparenting". This involved awarding nitrogen discharge allowances to users based on historical use, in this case on their highest productive year between 2001 and 2005. Many landowners saw this approach as inequitable, in enabling high polluters to remain high polluters, while capping those at lower levels at that level, thereby limiting their future opportunities. However, the need for flexibility was an important point in landowner negotiations. For farmers, the 'best year' allocation decision and the ability to trade allowed them some flexibility in their farming operations.

The success of the policy relied on estimating nitrogen discharges through an existing farm nutrient management model called OVERSEER $®$, designed to assist farmers in nutrient management decisions. This is because, while recorded levels of nitrogen in Lake Taupo provided information on the total actual emissions, it cannot break down the figures to individual farms - a necessary step for establishing a nitrogen market. The OVERSEER $®$ model, which estimates nitrogen emissions based on livestrock numbers, fertiliser applied and management practises, provides the basis for generating farm-specific figures that can be used to establish nitrogen discharge alowances. While this model-based approach was essential for enabling a cap and trade policy to be implemented, it is accepted by both farmers and the Regional Council that the model does not include some aspects of the nitrogen cycle (particularly losses into the atmosphere associated with dentrification) and therefore the actual measured nitrogen levels are likely to be lower than the model-based discharged allocation figures.

By allocating nitrogen discharge allowances, each consented farm can only leach as much nitrogen as the nitrogen discharge allowances they have been allocated. This is enforced through a requirement for approved management plans, a regular monitoring programme, and penalties for non-compliance under the Resource Management Act.

The imposition of a cap on nitrogen emissions was initially vigorously opposed by both farmers and foresters. Farmers argued that the cap would restrict stocking rates and make pastoral farming unviable in the long run. In the interactions with Regional Council staff it had become clear to farmers that the staff developing the policy knew little about farm systems and farm economics. The value of including agricultural science experts who could communicate effectively with council staff and with farmers was apparent. These experts, external to the Regional Council, remained involved throughout the policy process, smoothing the relationship between farmers and Regional Council, allowing each party to understand the other party's position. Foresters argued that their future land use options would be limited, as they would not have sufficient nitrogen discharge allowances allocated to them to enable change. 


\section{Box 3 | Using the market to tackle pollution}

Water quality trading is an economic instrument being used in many parts of the world to help improve water quality in degraded water bodies. A nutrient trading system controls nutrient discharges by setting the total amount of allowances to leach nutrients equal to an annual cap on leaching that will achieve the desired water quality. Each allowance permits its holder to discharge a set level of nutrients, for example $1 \mathrm{~kg}$ of nitrogen, from their property. An allowance can be used only once. It must be used on or after the date on the allowance. All nutrient sources included in the system monitor their nutrient loss and must surrender sufficient allowances to cover their discharges at the end of each trading year. If all sources comply, the goal is met.

Nutrient trading enables polluters to receive direct financial benefits for reducing their nutrient leaching. If a polluter has insufficient allowances to cover their nutrient loss, they must purchase additional allowances from the market. If a polluter has surplus allowances, they can sell the extra allowances. This helps to ensure that nutrient reductions take place cost effectively.Most trading programmes focus on the regulation of point sources (e.g. industrial or wastewater treatment plants) as it is easier to measure the pollutant discharges from these sources. Non-point sources (e.g. farmed or forested landscapes) are more challenging to regulate as the diffuse nature of their pollutant losses means makes them difficult to measure; hence most of these sources are not often regulated or included within trading programmes.

Source: Kerr, et al. (2012), "Nutrient Trading in Lake Rotorua: A Policy Prototype", Motu Note \#10, Motu Economic and Public Policy Research, Wellington.

\section{The Taupo nitrogen market}

An innovative feature of the policy was to allow landowners to buy, sell or lease nitrogen discharge allowances within the catchment (see Box 3). This responded to the farming community's desire for flexibility in using nitrogen discharge allowances and managing their operations according to need and demand. The nitrogen market permits the transfer of nitrogen discharge allowances around the Lake Taupo catchment. This allows any increases in nitrogen leaching to be offset by corresponding and equivalent reductions in nitrogen leaching within the catchment.

\section{The Lake Taupo Protection Trust}

The independent Lake Taupo Protection Trust was established to use public funds to achieve the required $20 \%$ nitrogen reduction through the buy-back of allocated nitrogen discharge allowances and to reduce the local economic and social impacts of the nitrogen cap. The Trust's strategic plan involved three main operations: purchasing farms within the catchment so as to shift them to low-nitrogen activities permanently; purchasing nitrogen discharge allowances from owners who opted to stay on their land while reducing their nitrogen output (farmers retain ownership of the land but change land use or management and receive a payment from the Trust); and investing in research to seek cost-efficient ways of using farmland differently to reduce nitrogen outputs. The Trust also covered the cost of benchmarking all farms to set their initial allocation. The NZD 79.2 million (excluding Goods and Services tax) fund was created with contributions from the Taupo District Council (22\%), Waikato Regional Council (33\%), and central government (45\%) - a share which reflected their individual stakes in maintaining the water quality of the lake. 


\section{Policy implementation and progress}

The Trust was set up in 2007, and achieved its nitrogen reduction target in 2015. The initial target of 153 tonnes was revised upwards to 170 tonnes as a result of court negotiations and benchmarking of farms. The three funding parties agreed to provide additional funds to meet the revised target. Given the fiscal constraints facing the central and local governments, agreement to provide these additional funds demonstrated the strength of commitment to completing the project and maintaining the partnership agreed at the start.

The cap-and-trade policy began in July 2011, although the activities of the Lake Taupo Protection Trust in buying up nitrogen discharge allowances had commenced in 2009. By 2013, all farms in the catchment had applied for resource consents and had been benchmarked for their nitrogen discharge allocation.

By mid-2015, the Trust had executed 23 trades in nitrogen discharge allowances equalling 151066 kilos of nitrogen, $\mathrm{kg} \mathrm{N}$ ) and there had been 12 other nitrogen discharge allowance trades between regulated farmers (totalling $17634 \mathrm{~kg} \mathrm{~N}$ ) (Table 2). By June 2012, 30 out of 180 farmers had engaged in at least one trade; 17\% of the cap had been traded, and there had already been three leases (short-term trades). ${ }^{3}$ Since the early trades, which were dominated by purchases by the Trust, the size and frequency of trades has fallen.

The trading price in 2012 was around NZD 300 per kilogram of nitrogen permanently removed from the crucial inflow. This price was largely determined by the Trust's trades so it does not necessarily reflect the long-run value of nitrogen in the catchment.

The monitoring process and inspection regime being implemented by Regional Council staff will be refined over time with the help of farming representatives. Monitoring is based around livestock numbers and cropping, with all farms providing their annual accounting records to the Regional Council. A priority system has been developed, with Priority 1 farms including farms close to the limits of their allowance, intensively farmed units and those farms where nitrogen discharge allowances have been sold. Farms in this category will receive one or two annual visits from Regional Council officers and an annual audit. Priority 2 farms are likely to receive an annual visit and an annual audit. 


\section{Table 2 | History of nitrogen discharge allowance trades in the Lake Taupo}

\begin{tabular}{|lcccccc|}
\hline Year & $\begin{array}{l}\text { Number } \\
\text { of trades } \\
\text { to LTPT }\end{array}$ & $\begin{array}{l}\text { Amount } \\
\text { traded to } \\
\text { LTPT } \\
(\mathrm{kg} \mathrm{N})\end{array}$ & $\begin{array}{l}\text { Number } \\
\text { of trades } \\
\text { to farmers }\end{array}$ & $\begin{array}{l}\text { Amount } \\
\text { traded to } \\
\text { farmers }\end{array}$ & Total trade & $\begin{array}{l}\text { Total } \\
\text { amount of } \\
\text { N traded } \\
\text { (kg N) }\end{array}$ \\
2009 & 3 & 17,242 & 3 & 12,184 & 6 & 29,426 \\
\hline 2010 & 5 & 56,100 & 2 & 3,500 & 7 & 59,600 \\
2011 & 4 & 43,614 & 2 & 1,311 & 6 & 44,925 \\
\hline 2012 & 9 & 24,311 & 3 & 362 & 12 & 24,673 \\
\hline 2013 & 2 & 9,799 & 1 & 113 & 3 & 9,912 \\
\hline $2014^{*}$ & 1 & 0 & 1 & 164 & 1 & 164 \\
\hline 2015 & 1 & 19,234 & 0 & 0 & 1 & 19,234 \\
\hline Total & $\mathbf{2 4}$ & $\mathbf{1 7 0 , 3 0 0}$ & $\mathbf{1 2}$ & $\mathbf{1 7 , 6 3 4}$ & $\mathbf{3 6}$ & $\mathbf{1 8 7 , 9 3 4}$ \\
Notes: * This represents the period to June 2014. LTPT= Lake Taupo Protection Trust. & \\
\hline
\end{tabular}

Priority 3 farms may be visited every two years. Monitoring is a cost to landowners as part of their resource consent. The newness of the programme means it is too early to know if existing dissatisfaction will translate into breaches of the rules and the need for enforcement.

Landowners in the catchment express their continued commitment to high water quality in the lake, and recognise the influence of pastoral farming activities on lake water quality. Most farmers now accept the cap-and-trade policy. Mitigating practices employed by farmers, such as better management of effluent. New lower-nitrogen ventures are emerging in the catchment, such as growing olives, farming dairy sheep and producing and marketing "sustainable" beef (see later box on "Taupo branded beef"). The use of the model OVERSEER $\otimes$ is essential to the cap-and-trade programme, providing incentives for farmers to reduce nitrogen-emitting practices. 


\section{Environmental and economic impacts}

\section{Environmental impacts}

Because the residence time of water in Lake Taupo is around 15 years and nutrients can stay in groundwater for up to 100 years, monitoring the quality of the water in the lake cannot give any clear indication of the success of the policy package to date. In any case, the policies were implemented to avoid a potential future problem (lake water quality is still very high) rather than to address immediate concerns. Therefore, the best indications of success are that the components of the policy package have been fully implemented, there have been no issues to date with non-compliance, and the Trust has successfully permanently retired $20 \%$ of the original nitrogen discharge allowances. There have also been complementary environmental impacts, particularly carbon sequestration, from the reforestation of more than 5000 ha of land to pine plantations.

Whether achieving this target will meet the environmental goal in the long term depends on both scientific and social factors. First, the farm level regulation and monitoring is based on a model so it is not a perfect measure of actual leaching. Second, the adequacy of the limits on leaching to achieve lake outcomes is to some extent uncertain, as it is subject to the challenge of dealing with non-point pollution sources. From the social side, the long-run goal will depend on the regulations remaining acceptable to landowners, and their long-term compliance with these regulations. In the future, situations may arise that mean compliance could require stronger legal structures. For example, if farmers wanted to increase production in response to higher commodity prices and leach more nitrogen than is permitted under their nitrogen discharge allowance, prices would be likely to rise or as a result of higher demand for a fixed or lower types of allowance. This could increase the incentive not to comply rather than purchase higher priced nitrogen discharge allowances. 


\section{Economic impacts}

To date, the overall loss of profit to farmers and foresters is probably relatively small because the grandparenting allocation allowed most to continue their current practices. The Trust has almost certainly provided some net gains to farmers from their sale of nitrogen discharge allowances. However, as agricultural intensification pressures rise in response to rising operational costs, agricultural losses in the catchment are likely to occur because of the overall nitrogen cap. There are some suggestions that, anticipating these losses of future profit, some land values may have fallen. However, there has been no assessment of land prices to determine the extent, if any, of changes in land values or whether any change in land value has been compensated by the (new) value of nitrogen discharge allowances for that land.

The administrative costs associated with implementing the nitrogen cap (e.g. benchmarking farms) and the nitrogen market have been estimated at NZD 175000 in 2011, falling to about NZD 100000 per year in the future (Duhon et al. 2014). Should future compliance be more difficult to enforce then these costs may rise. Another benefit of the policy package and the environmental certainty it provides is the ability to develop products with credible green branding. Rather than each farm making an individual sustainability case, the Regional Council certifies the Lake Taupo catchment as sustainably managed. Taupo Beef is one initiative that has capitalised on this branding (see Box 4).

\section{Box 4 | Taupo branded beef}

Given that the nitrogen cap prevents farmers from increasing their cattle herds without purchasing additional nitrogen discharge allowances or adjusting farming practices, some local farmers have found an innovative way of making their cattle farms profitable. Since 2009, Mike Baron has been buying recently weaned animals and finishing them before their second winter, cutting costs and nutrient loss. Young stock leach less nitrogen than mature cattle. The farmer has also adapted farm practises, avoiding applied nitrogen and focusing on managing clover content to fix nitrogen and raise pasture quality. He has set about adding value to his produce with a brand built on protecting the lake: Taupo Beef. The value proposition to consumers is that buying meat produced under the catchment-wide cap is protecting the lake and they should pay premium for it. The Waikato Regional Council has given an environmental "tick" to this beef, recognising environmentally sustainable farming practices and compliance with the new rules to protect Lake Taupo's water quality. This farm, along with Hurakia Station, a Maori trust farm, supplies a number of Taupo restaurants under the brand "Taupo Beef: grown right here".

Source: http://www.ruralnewsgroup.co.nz/rural-news/rural-management/bartons-branded-beef-initiative; http://www.makearipple.co.nz/Local-Heroes/taupo-beef/. 


\section{Social impacts}

The benefits from trading have been largely economic. However, the flexibility provided

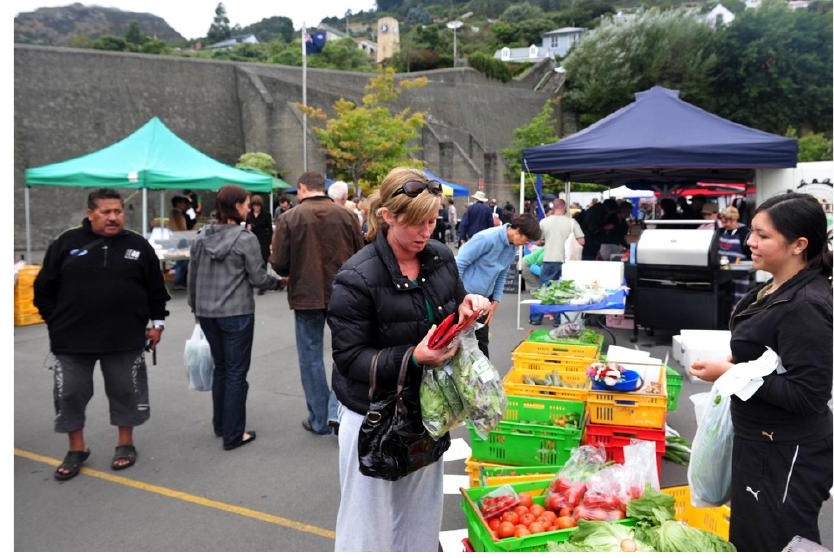
by trading is also likely to have affected the acceptability of the regulations for some farmers. For instance, trading allows for the intensification of land use, which is particularly valuable to Maori farmers (whose land was relatively underdeveloped) and to dairy farmers who want to capitalise on high dairy prices. Selling nitrogen discharge allowances also allowed some farmers to retire without selling their farms during a period when selling land was difficult because of regulatory uncertainty.

The Trust formed close relations with Ngati Tuwharetoa in the catchment, and over 50\% of nitrogen discharge reductions have come from their lands. While Ngati Tuwharetoa owners potentially held market power because of their large land holdings and the Trust's obligation to purchase $20 \%$ of the nitrogen allocations, the Trust's decision to pay a set price to all Ngati Tuwharetoa owners reduced this power. Dealing with the Trust was particularly appealing to Ngati Tuwharetoa groups because the Trust was able to facilitate carbon trades under the recently introduced national carbon trading legislation at the same time as making nitrogen discharge reduction payments, which provided Ngati Tuwharetoa groups with a regular income from new forestry on their lands. Deals with the Trust that take nitrogen out of the catchment, as opposed to simply transferring it to another landowner, also fit better with Ngati Tuwharetoa's cultural aspirations.

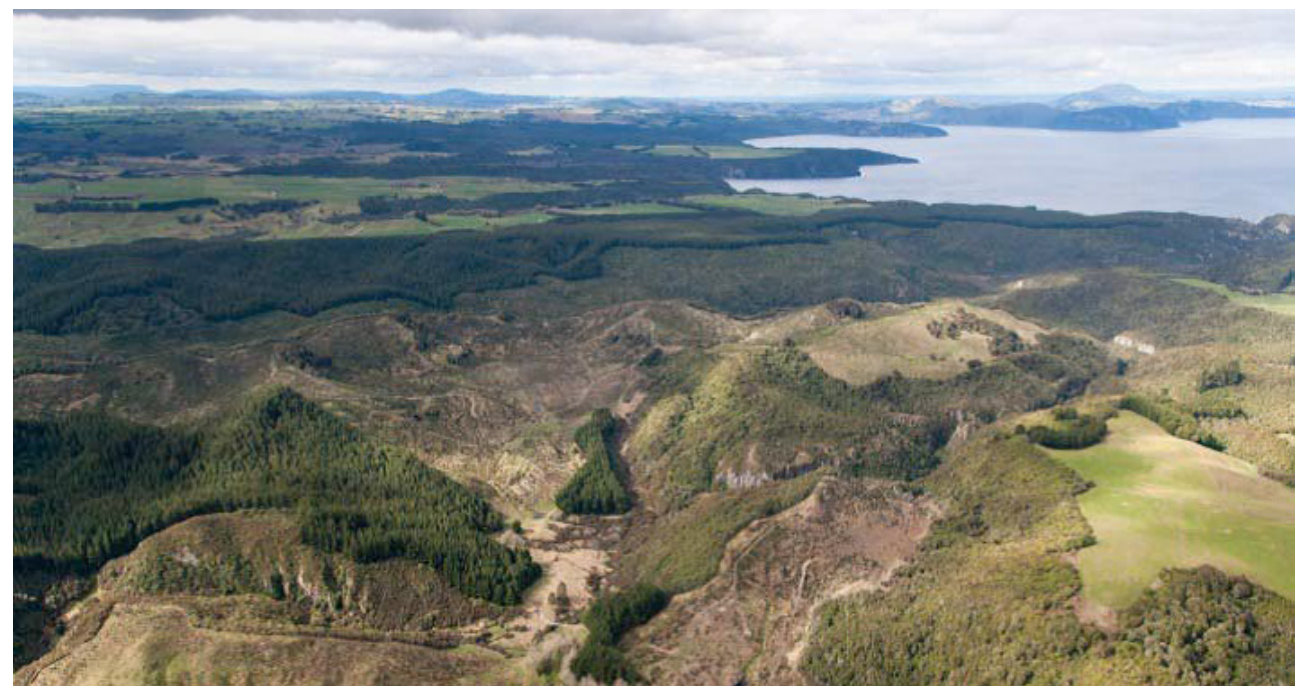




\section{Lessons learned}

The Taupo cap-and-trade programme is a unique and innovative initiative addressing the issue of diffuse nitrogen

emissions through a market. The trading component of the policy package is achieving what it was theoretically meant to do - it is providing the flexibility for land to move to its highest and best use and still meet the overall nitrogen load reduction targets. The regulatory cap was necessary to achieve, with certainty, the community goal of maintaining a healthy lake into the future. Trading has allowed this cap to be imposed in a more efficient and flexible manner, theoretically enabling the regulatory cap on emissions to be met at lower cost than stand-alone regulation. Compared to achieving the cap through regulation alone, the creation of the market provides a net benefit to the farmers in the catchment. The flexibility afforded farmers by the ability to trade and the "best year" allocation decision, whereby allowances were allocated based on framers' highest productive year between 2001 and 2005, was important in landowner negotiations.

The purchase and trading in nitrogen discharge allowances is inextricably linked to the resource consent process and would not be possible without a robust regulatory and monitoring system tracking and controlling nitrogen discharge allowance trading. Scientific research in developing a farm management tool to model diffuse nitrogen emissions was also essential to the solution. The use of OVERSEER® was contentious throughout the policy process because it is a model and unable to measure actual nitrogen emissions. Yet, the advantage of a model is that it is objective, treating all farms and actions consistently. OVERSEER® continues to be used to estimate farmspecific nitrogen emissions. In addressing diffuse emissions in the future, the use of such modelling techniques is becoming commonplace and the accuracy of these models will become critical to maintaining the credibility of policies developed using them.

The journey to policy implementation was lengthy, requiring leadership and commitment from politicians and staff at all levels of government. Finding a successful solution to retain a clean lake was seen by many as contributing to a legacy project. The relevance of the lake for New Zealanders and its economic importance for tourism were drivers for change. For landowners, the attributes of leadership and commitment led to important compromises that allowed them to continue to operate their businesses. 
Compromises were essential to successful implementation. Methods included effective consultation, the policy submission process and the formal hearings and court processes. These compromises were important in securing the acceptance of the programme by farmers. A review process for 2018 also played an important role in building consensus; it will review the $20 \%$ reduction, the contributions of nitrogen from various sources and the activities of the Trust.

To a large degree, therefore, the objectives of the policy have been achieved through a combination of government partnerships, the commitment of the local indigenous people, sufficient scientific knowledge, and a series of innovative economic and regulatory actions designed to overcome negative economic outcomes. The success of the buy-back of nitrogen discharge allowances stems from the Trust's independence from government and the fortuitous timing of the introduction of the New Zealand carbon market coinciding with the Taupo cap-and-trade programme, which made conversion from livestock farming to forestry even more attractive: some landowners are eligible for both a nitrogen discharge reduction payment and benefits from carbon trades with a company required to offset their carbon emissions. The lesson here is the value of an awareness of synergies that might be available in the wider policy environment.

For New Zealand - and indeed other countries - to benefit fully from these lessons, the expertise gained during the process needs to be retained and effectively communicated to communities grappling with their own water quality issues. Whether this approach, or variants of it, will be perceived valuable to adopt in other catchments will depend on local economic, geophysical and political circumstances. The Taupo nitrogen market has demonstrated the feasibility of a cap-and-trade system for agricultural non-point sources and provided one model for such a system. It shows that it is technically feasible to include non-point sources within a cap and trade water quality market, that such a market can function, and that once property rights are clearly established, the additional cost of allowing trading is low.

\section{ENDNOTES}

1. Ngati Tuwharetoa (iwi) are the kaitiaki (guardians) of Lake Taupo and have applied their kawa (principles, values) and tikanga (rules) that reflect their relationship with the lake. Ngati Tuwharetoa are also Treaty partners with the Crown (i.e. Government of New Zealand) and hold legal title to the bed of the lake and its tributaries.

2. Increases in land value are not subject to a capital gains tax in New Zealand. Most data are derived from Duhon et al. (2014) or from trading records provided by the Waikato Regional Council.

3. Most data are derived from Duhon et al. (2014) or from trading records provided by the Waikato Regional Council. 


\section{References}

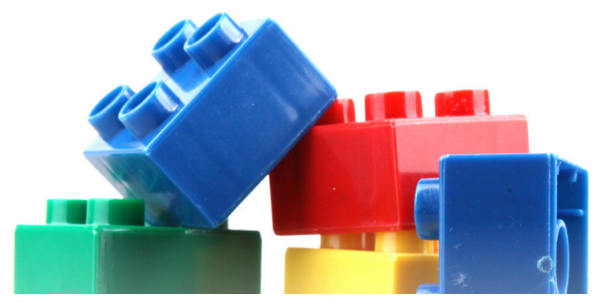

Cameron, M. (2009), "Implications of agricultural change in the Waikato Region: Current trends and future scenarios", Environment Waikato Technical Report 2009/28, www.waikatoregion.govt.nz/ PageFiles/15159/TR0928.pdf.

Duhon, M., H. McDonald, and S. Kerr (2014), Nitrogen Trading in Lake Taupo: An Analysis and Evaluation of an Innovative Water Management Policy", Motu Working Paper 14-14. Wellington: Motu Economic and Public Policy Research.

Environmental Court (2008), "Interim Decision of the Environment Court, Environment Court, Auckland. www.waikatoregion.govt.nz/PageFiles/7058/Interim_Decision.PDF [Accessed 5 September 2014].

Kerr, S., S. Greenhalgh and G. Simmons (2015), The Taupo Nitrogen Market: The world's only diffuse source trading programme. Was it worth doing and should similar programmes be used elsewhere?

Kerr, Suzi, Hugh McDonald, and Kit Rutherford (2012), "Nutrient Trading in Lake Rotorua: A Policy Prototype", Motu Note \#10, Motu Economic and Public Policy Research, Wellington, www.motu.org.nz/ publications/detail/nutrient_trading_in_lake_rotorua_a_policy_prototype.

Lake Taupo Protection Trust (2014), News and Events, www.laketaupoprotectiontrust.org.nz/page/ lake_7.php [Accessed 5 September 2014].

Ledgard, S. (2000), "Sheep and beef farming systems in the Lake Taupo catchment from the late 1970 s to present: Preliminary estimate of potential changes in nitrate leaching", Report for Environment Waikato.

Phillips, Y. (2009), “Waikato Economic Report 2009”, Environment Waikato Technical Report 2009/26.

Statistics New Zealand (2011), New Zealand in profile: 2011, www.stats.govt.nz/browse_for_stats/ snapshots-of-nz/nz-in-profile-2011.aspx.

Waikato Regional Council (WRC) (2011), Variation 5 - Lake Taupo Catchment: Operative version, http://www.waikatoregion.govt.nz/PageFiles/3918/V5\%200perative\%20Version.pdf [Accessed 5 September 2014].

Yerex, S. (2009), "Lake Taupo. The strategy and the lessons", Report prepared for Kellogg Rural Leadership Programme 2008.

Young, J. (2007), Statement of evidence of Justine Young, before the Environment Court, January 2007. 
19 | OECD ENVIRONMENT POLICY PAPER NO. 4 ๑ OECD 2015 


\section{The Lake Taupo Nitrogen Market in New Zealand}

\section{Lessons in environmental policy reform}

Nitrogen run-off from farming and other land uses was threatening to undermine the pristine waters of Lake Taupo - New Zealand's largest and most iconic lake - and to damage a range of economic and cultural activities. In 2011 the regional government introduced a water quality policy package with three components: (1) a cap on nitrogen emission levels within the Lake Taupo catchment; (2) the establishment of the Taupo nitrogen market; and (3) the formation of the Lake Taupo Protection Trust to fund the initiative. This bold policy experiment is globally unique: it is the only trading programme or market where diffuse sources of pollution operate under a cap.

\section{The OECD Environment Policy Papers}

Designed for a wide readership, the OECD Environment Policy Papers distil lessons from many of today's environment-related policy issues, drawing on a wide range of OECD work. In the form of country case studies or thematic reviews across countries, the papers highlight practical implementation experience. They are available in either English or French, with a summary in other languages when possible.

1. OECD (2013), "Climate and Carbon: Aligning prices and policies", OECD Environment Policy Papers, No. 1, OECD Publishing, Paris, http://dx.doi.org/10.1787/5k3z11hjg6r7-en.

2. OECD (2013), "The Swedish Tax on Nitrogen Oxide Emissions: Lessons in environmental policy reform", OECD Environment Policy Papers, No. 2, OECD Publishing, Paris, http:// dx.doi.org/10.1787/5k3tpspfqgzt-en.

3. OECD (2014), "Greening Household Behaviour: A review for policy makers", OECD Environment Policy Papers, No. 3, OECD Publishing, Paris, http://dx.doi. org/10.1787/5jxrcllp4gln-en.

4. OECD (2015), “The Lake Taupo Nitrogen Market in New Zealand: Lessons in environmental policy reform", OECD Environment Policy Papers, No. 4, OECD Publishing, Paris.

\section{Contact}

For further information, please contact:

\section{Nils Axel Braathen}

Environmental Policy Analyst

OECD Environment Directorate

Tel.: +33 (0)1 45247697

Email: Nils-Axel.Braathen@oecd.org

\section{Cover photo}

(c) Marcel Alsemgeest 